\title{
A HISTORY AND ANALYSIS OF THE EVOLUTION OF ACTION AND PARTICIPATORY ACTION RESEARCH
}

\author{
Steven Darryl Jacobs \\ George Brown College
}

\begin{abstract}
Action research is a type of research which is conducted with research participants rather than on participants. This premise democratizes research, resulting in transformative potential, while addressing issues such as power and hierarchy which are present in traditional positivist research approaches, allowing those affected by the research to benefit from a more democratic research experience: According to Habermas, "in a process of enlightenment, there can only be participants". However, as with social science research, or perhaps any method of research, there are different forms of action research which have evolved over time. This paper describes the worldviews that have informed the evolution of action research and examines three different forms of action research with respect to assumptions value, beliefs, and claims to truth inherent with each form. These three main forms may be thought of as "umbrella" terms for the forms of action research, with various threads of action research originating and continuing to originate from each form. Lastly, this paper explores one thread of action research-participatory action research. The reason for focusing on participatory action research specifically is that this type of action research has grown in popularity recently within social sciences research due to the opportunity for new insight for all research participants. Further, participatory action research allows for joint knowledge-production, may draw attention to previously neglected areas of qualitative research, and is therefore relevant to a specific community. For a researcher considering employing participatory action research, it is helpful to understand the historical and philosophical underpinnings of action research in general in order to better understand the specific intricacies and characteristics of participatory action research.
\end{abstract}

KEYWORDS: Action research, participatory action research 


\section{ACTION AND Social SCIENCE RESEARCH}

Action research is the name for a broad family of research practices all of which involve learning by doing (O'Brien, 1998). There are three main forms of action research which have evolved over time as researchers found new ways to expand the original aim and purposes of action research: technical, practical and emancipatory (Carr and Kemmis, 1986; Chenail, St. George, Wulff, \& Cooper, 2012; Grundy, 1988; Habermas, 1972; Noffke 1997; Noffke \& Somekh, 2011; Somehk \& Lewin, 2011). The evolution of these forms of action research describe in this paper because they are associated with the evolutions which have occurred within the broader social sciences. These three main forms can be thought of as "umbrella" forms of action research, with various threads of action research originating and continuing to originate from each form. While similar, in that all involve learning by doing, the forms of action research have different goals, assumptions, and claims to truth, and therefore, are suited to different types of research paradigms such as a positivist, interpretative, or critical science paradigm.

The purpose of this paper is three-fold: to describe action research as a research methodology; to examine the worldviews in social science that have informed the evolution of the three main forms of action research; and to further describe a thread of action research which has grown in popularity recently: participatory action research.

Participatory action research (PAR) has been chosen as a central focus for this paper for a variety of reasons. Firstly, PAR has grown in popularity recently within social sciences research due to the opportunity for new insight for all research participants. Secondly, PAR allows for a joint process of knowledge-production which leads to new insights on the part of both researcher and those typically described as research subjects (Bergold \& Thomas, 2012). Thirdly, due to the way in which PAR introduces knowledge and researchrelated questions in a radical manner, it draws attention to previously neglected areas of qualitative methodology (Bergold \& Thomas, 2012). As opposed to traditional research which may be carried out under any social condition, PAR requires a democratic, social, and political context, therefore offering insight in a society's self-concept, allowing for research which is relevant to a specific community (Bergold \& Thomas, 2012; Lucock, Barber, Jones, \& Lovell, 2007). Prior to embarking on a PAR project, it is important for one to understand the historical and philosophical underpinnings of action research in general in order to better understand the intricacies of participatory action research.

\section{ACTION ReSEARCH AND METHODOLOGY}

Action research as methodology can be described as learning by doing-participants identify a problem, act to resolve it, evaluate their efforts, and if not satisfied, try again (O'Brien, 1998).

Within action research, as opposed to other forms of inquiry such as consulting or daily problem-solving, there is an emphasis on scientific inquiry, meaning the researcher studies a problem systematically, ensuring an intervention is informed by theoretical considerations (O'Brien, 1998). Action research differs from traditional research as the processes of research and action are integrated within a single action research process 
(Somekh, 1995). It can be practical, participative and collaborative, emancipatory, interpretive, and critical (Reason \& Bradbury, 2001; Zuber-Skerritt, 1992), depending upon which thread of action research is used.

The purpose of action research is to create outcomes to create change and improve the situation (action) in which a practice takes place (Reason \& Bradbury, 2001; Somekh, 1995; Zuber-Skerritt, 1992). The validity of action research does not depend upon cause and effect, but rather, how well the research has described the multiple determinants of actions, interpersonal relationships, and interactions (Somekh, 1995), or what Elliott (1993) called situational understanding. This is achieved by the action researcher studying a topic unconditionally, which has the possibility of influencing the destiny of the organization and participants involved (Ludema, Cooperrider, \& Barrett, 2001). Often the researcher spends time refining methodological tools in order to suit the demands of the project and during the process of collecting, analyzing, and presenting the data in an ongoing cyclical manner (O’Brien, 1998). The link between research, action and practice aligns with Dewey's (1938) view that control of individual actions are effected by the entire situation in which one is involved, in which one shares, and in which one co-operates or interacts with others.

Action research is often associated with the work of psychologist Kurt Lewin, who is generally credited with coining the term action research (Adelman, 1993; Borg, Gall, \& Gall, 1993; Greenwood \& Levin, 1998; Gustavsen, 2001; Herr \& Anderson, 2015; Pine, 2009; Reason \& Bradbury, 2001; Savin-Baden \& Wimpenny, 2007; Streubert \& Carpenter, 2011; Young, 2013). Lewin was not the first researcher to adopt action research however he was the first to develop a theory of action research which legitimized it within the social sciences (Herr \& Anderson, 2015). Lewin's work confirmed the idea that reflections on knowing and action can lead to actionable theory (Pine, 2009). While many view Kurt Lewin as the first researcher to utilize action research principles in his work in the 1940s (Greenwood \& Levin, 1998; Passmore, 2001), other scholars also mention the work of Collier, Kippitt and Radke, (Masters, 1995), while McTaggert (1992) cites work by Gstettner and Altricher who discuss a physician in 1913 who facilitated a community development initiative with prostitutes in Vienna.

Lewin's work followed a "spiral of steps" which consisted of repetition of stages of his research: identifying a general idea, engaging in investigation, creating a general plan, developing the first action step, implementing the first action step, then evaluating and revising the general plan (Pine, 2009). Lewin then would spiral into a second cycle of activities: developing the second action step, implementing, evaluating, and revising the general plan, developing the third action step, implementing, evaluating, revising, and so on continuing for three, four, and five cycles (Pine, 2009).

Action research also has a long history within education. Continuing (and at times coinciding) with the work of Lewin and his colleagues, was the work of Stephen Corey at the Teachers College, Columbia University in the 1940s and 1950s (Noffke, 1997; Pine, 2009). Corey (1953) advocated that action research be utilized as an alternative to 
traditional research methodologies in education. Just as Lewin believed participants should be involved in the research process and not simply objects of it, Corey believed that actual teachers should be equal partners in the research process by playing a major role in the design of classroom research and in data collection and interpretation (Pine, 2009; Zeichner, 2001). As with Lewin's "spiral of steps", Corey (1953) identified similar stages and cycles of research which could be changed due to the reflective nature of the research process, with each cycle affecting previous and subsequent cycles (Pine, 2009). Similar to Lewin's spiral of steps, Corey's stages are not linear, but are seen as interacting circles of research activities (Pine, 2009). These types of reflective, flexible, cyclical, and dynamic processes created by Lewin have been used by other researchers and scholars within a variety of action research forms (Hopper, 2006; Koch \& Kralik, 2006; Noffke \& Somekh; 2011; Sagor, 1992).

\section{WORLDVIEWS IN SOCIAL SCIENCE RESEARCH AND ACTION RESEARCH}

Three distinct worldviews within the social sciences - positivism, interpretivism, and critical science - have informed and parallel the evolution of action research. The philosopher Habermas (1971) identified 3 categories of knowledge: technical, practical and emancipatory, within which forms of action research can be categorized. These three paradigms are most commonly used to guide social and organizational research (Thomas, 2010), and they are cited by other scholars when engaging in discussions about the evolution of social sciences and of educational research (Carr \& Kemmis, 1986; McCutcheon \& Jung, 1990; Thomas, 2010). ${ }^{1}$

Habermas (1971) believed that knowledge and human interests were inseparable and had a strong influence on action research (Herr \& Anderson, 2015). He maintained that it is unreasonable to assume valid knowledge can only be obtained through empirical-analytical methodologies, and by a relationship in which the research is separate from the subject being researched (Herr \& Anderson, 2015). Habermas (1971) believed this type of separation is an illusion and can be challenged by a process of self-reflection (Herr \& Anderson, 2015). Habermas (1971) contended truth can only be obtained in settings where all claims are open to critical scrutiny without fear or preference (Kemmis, 2001). Habermas (1971) argued that objectivism is not the sole valid knowledge, and as previously stated, presented three distinct avenues of interest a researcher may pursue in the pursuit of knowledge: technical, practical, and emancipatory (Herr \& Anderson, 2015; Maguire, 1987). Carr and Kemmis (1986) and other scholars (Grundy, 1988) have identified an evolution of three forms of action research based on Habermas's (1972) theory of knowledge-constitutive interests:

\footnotetext{
${ }^{1}$ My use of the terms paradigm and worldviews interchangeably is intentional, and is based on Kuhn's (1962) belief that scientific research occurs within an accepted framework which organizes all thinking and perceptions-a paradigm (Cameron \& Singh, 2013; Polit \& Beck, 2012; Reason \& Bradbury, 2001). Therefore, a paradigm establishes parameters and sets borders for scientific research and inquiry (Crotty, 1998).
} 
- technical action research is guided by an interest in improving control over outcomes and is based on a positivist paradigm;

- practical action research is guided by an interest in educating or enlightening practitioners so they can act more wisely and prudently and is based on an interpretivist paradigm;

- emancipatory action research is guided by an interest in emancipating people and groups from irrationality, unsustainability, and injustice and is based on a paradigm of praxis and critical theory.

Table 1

\begin{tabular}{|c|c|c|c|c|c|c|}
\hline $\begin{array}{l}\text { Forms of } \\
\text { Action } \\
\text { Research }\end{array}$ & Goals & Assumptions & Values & $\begin{array}{l}\text { Claims to } \\
\text { Truth }\end{array}$ & $\begin{array}{c}\text { Related } \\
\text { Social } \\
\text { Science } \\
\text { Paradigm } \\
\end{array}$ & References \\
\hline Technical & $\begin{array}{l}\text { Problem-solving } \\
\text { through } \\
\text { generalizations } \\
\text { and empirical } \\
\text { facts }\end{array}$ & $\begin{array}{l}\text { Researcher neutrality } \\
\text { is necessary, the } \\
\text { researcher is } \\
\text { considered an } \\
\text { expert/authority due } \\
\text { to their knowledge } \\
\text { and skill }\end{array}$ & $\begin{array}{l}\text { Empirical testing } \\
\text { of inductive and } \\
\text { deductive } \\
\text { hypotheses }\end{array}$ & $\begin{array}{l}\text { Truth can be } \\
\text { measured and } \\
\text { quantified }\end{array}$ & Positivism & \multirow{3}{*}{$\begin{array}{l}\text { Carr \& Kemmis, } \\
1986 \\
\text { Habermas, } \\
1971,1972 \\
\text { Herr \& } \\
\text { Anderson, } \\
2015 \\
\text { Maguire, } 1987 \\
\text { Masters, } 1995 \\
\text { O’Brien, } 1998 \\
\text { Walsham, } 1993\end{array}$} \\
\hline Practical & $\begin{array}{l}\text { Illuminate } \\
\text { understanding of } \\
\text { participants }\end{array}$ & $\begin{array}{l}\text { Researcher is the } \\
\text { expert interpreter of } \\
\text { data, although } \\
\text { participants } \\
\text { situations and } \\
\text { environments are } \\
\text { considered }\end{array}$ & $\begin{array}{l}\text { Self-education for } \\
\text { Participants(s) }\end{array}$ & $\begin{array}{l}\text { There are no } \\
\text { correct, } \\
\text { incorrect } \\
\text { theories Truth } \\
\text { is judged } \\
\text { according to } \\
\text { how } \\
\text { appropriate } \\
\text { and relevant it } \\
\text { is to researcher } \\
\text { and } \\
\text { participants }\end{array}$ & Interpretive & \\
\hline Emancipatory & $\begin{array}{l}\text { To connect } \\
\text { personal and } \\
\text { political aspects } \\
\text { in order to } \\
\text { transform } \\
\text { situations and } \\
\text { challenge } \\
\text { environments of } \\
\text { oppression and } \\
\text { domination }\end{array}$ & $\begin{array}{l}\text { Researcher (and } \\
\text { participant(s)) are } \\
\text { active in research } \\
\text { process }\end{array}$ & $\begin{array}{l}\text { Critical reflection } \\
\text { on how } \\
\text { understand-ings } \\
\text { are distorted or } \\
\text { constrained by } \\
\text { power relations }\end{array}$ & $\begin{array}{l}\text { Truth is } \\
\text { achieved when } \\
\text { one acts upon } \\
\text { the conditions } \\
\text { one faces in } \\
\text { order to } \\
\text { change them }\end{array}$ & $\begin{array}{l}\text { Critical } \\
\text { Science }\end{array}$ & \\
\hline
\end{tabular}

Inherent within action research is a worldview based on the assumption that generalized solutions may not fit particular groups of people or contexts and the purpose of inquiry is to find appropriate solutions for the particular dynamics within a local situation (Stringer, 2007). Teachers, human service practitioners, and health workers often find that "theoretical knowledge of the academic world has limited relevance to the exacting demands of their everyday professional lives" (Stringer, 2007, p. 5). Further, objective and generalizable knowledge embedded in social and behavioral research often has little relevance to the experiences and situations they encounter in daily work and "has little application to the difficulties they face" (Stringer, 2007, p. 5). Many theorists argue that the quality of relationships within social settings directly impacts the quality of people's experiences and therefore, the quality of outcomes of human enterprises, including research (Stringer, 2007). 


\section{Technical Action Research \& the Positivist Science Paradigm}

Epistemology \& Ontology. Social science research in the West has been heavily influenced by a positivist worldview (Reason \& Bradbury, 2001) based on the philosophical concepts of August Comte (Thomas, 2010). This perspective views science as separate from everyday life and values a relational distance between researcher and that (or who) which is being researched (Reason \& Bradbury, 2001). Just as a positivist perspective adheres to an assumption that behaviour is objective and testable, and generalizable and predictable (McCutcheon \& Jung, 1990), the technical form of action research focuses on a need to control natural and social realms (Herr \& Anderson, 2015). Within positivism exists an epistemology that knowledge consists of facts (Walsham, 1995) and is objective and quantifiable (Thomas, 2010). Technical action research has an epistemology in which knowledge is gained through a disinterested stance towards the issue being investigated and knowledge is generated through causal explanations and instrumentation (Herr \& Anderson, 2015). Positivism is based on an ontology which considers reality as independent of social construction and is objectively given, with measurable utilizing properties which are independent of the researcher and their instruments (Thomas, 2010), while technical action research is based on an ontology of a single measureable reality (Masters, 1995).

Belief. Researchers working within the positivist paradigm believe in an objective, real world (Thomas, 2010), while technical action research has a belief that researcher bias can and should be eliminated and/or minimized (McCutcheon \& Jung, 1990). This form of action research is a type of problem-solving research, with success measured by how well the project achieved its stated goals (Kemmis, 2001). Technical action research does not however question the goals of the project, nor does it consider how the situation or environment under examination has been socially, discursively, and historically constructed (Kemmis, 2001).

Claims to Truth. Positivism uncovers truth and presents it by empirical means (Henning, van Rensburg, \& Smit, 2004). The positivist paradigm has a claim to truth which states that truth is discovered by conducting controlled studies designed by the researcher based on current knowledge of the phenomenon under investigation (Langford \& Young, 2013). The aim of research within a positivist perspective is explanation, control, and prediction (Cameron \& Singh, 2013; Langford \& Young, 2013). The technical form of action research follows a similar claim to truth which holds that knowledge and truth is achieved from data which is experienced and verified between independent observers (O'Brien, 1998); in other words, truth can be measured. Relying primarily on quantitative measures, the researcher engages in empirical testing and employs inductive and deductive hypotheses to demonstrate relationships among variables through mathematical means ( $0^{\prime}$ Brien, 1998).

Example. This form of action research was employed by researchers such as Kurt Lewin in 1947, Corey in 1953, and Lippitt and Radke in 1946 due to its emphasis on researcherled problem-solving (Masters, 1995). The researcher(s) identified a problem and devised an intervention, discussed this with participants and they agreed to implement the 
intervention (Masters, 1995). Communication was mainly two-way between the researcher and the group and back to the researcher (Masters). Lewin's work in the 1940's spawned a roughly 40-year time period in the U.S. of using a technical approach to action research which manipulated isolated variables (Herr \& Anderson, 2015). This research was seen as conventional social science with researcher authoritarian control aimed at producing a specific desired outcome (Greenwood \& Levin, 1998).

An example of the use of technical action research is a study by Souleles (2012) who wanted to determine if Facebook could be embedded in the structure of an undergraduate visual communication study unit. As stated in their study, technical action research is often used to address a pre-defined theory, hypothesis, or problem whereby the researcher supervises an intervention among research participants (Souleles, 2012). The relationship between the researcher and the participants is technical and facilitatory in that the researcher is the expert who takes responsibility of the different stages of planning, implementation and reflection (Grundy, 1982; Holter \& Schwartz-Barcott, 1993). Consistent with a positivist science paradigm, this study followed a researcher/participant dynamic in which the research participants where regarded more as instruments, versus agents of change (Grundy 1982; Souleles, 2012). Lastly, the author justifies their use of technical action research since the nature of the task was pre-defined and took place over a short period of time (Soulesles, 2012).

\section{Practical Action Research and the Interpretivist Paradigm}

Epistemology \& Ontology. The interpretivist perspective is often attributed to the work of Max Weber who felt the human science paradigm is concerned with understanding (Crotty, 1998). A practical action research perspective allows a measure of flexibility not available to action researchers working within a technical paradigm (McCutcheon \& Jung, 1990). Practical action research assumes that the context of the situation or environment is important, and the intentionality of participants is probed, as well as the dynamics of the social relationships (McCutcheon \& Jung, 1990). Interpretivism has an epistemology that knowledge is an act of interpretation and that events are understood through mental processes of interpretation which is influenced by interaction within social environments (Thomas, 2010). The practical form of action research also has an epistemology which is directed towards gaining knowledge and understanding through interpretation, and the researcher utilizes primarily interpretative methodologies such as hermeneutic interpretation to obtain an understanding of a given situation (Herr \& Anderson, 2015). Both researcher and participants come together to identify a problem and their underlying causes and possible interventions (Masters, 1995). The interpretivist paradigm has an ontology whereby it is held that social reality is a product of processes by which participants negotiate the meanings of situations and actions (Crotty, 1998), and that multiple realities exist (Thomas, 2010). Practical action research also has an ontology that multiple realities are possible and are constructed and holistic (Masters, 1995). This interpretative understanding aims to generate knowledge to inform and guide practical judgments and decision making of practitioners (Herr \& Anderson, 2015; Kemmis, 2001). Practitioners within this form of action research aim to improve their practices and also 
"see how their goals and the categories in which they evaluate their work are shaped by their ways of seeing and understanding themselves in context" (Kemmis, 2001, p. 92).

Belief. Researchers within the interpretivist paradigm believe that events are understood by active mental work and understanding occurs by the meaning people make out of the phenomenon (Masters, 1995). Practical action researchers also believe in a process of selfeducation for the participant, but may also aim to produce findings which can help others to see things more clearly and/or a goal of understanding and changing the researcher as much as the subjects involved in the project (Kemmis, 2001).

Claims to Truth. As does the interpretivist paradigm, the practical form of action research has a claim to truth which states there are no correct or incorrect theories (Walsham, 1993), but theories are instead judged according to how appropriate and relevant they are to the researcher and participants (Thomas, 2010). The practical form of action research retains the ideal of the researcher objectivity as a passive collector and interpreter of data (O’Brien, 1998). This form typically involves changes with individuals directly involved in the change process and interventions tend to be short lived when these individuals leave the environment or new people arrive (Holter, Schwartz-Barcott, 1993).

Example. Classroom action research is a thread of action research aligned with the practical form (Kemmis \& McTaggart, 2005). This thread typically is conducted by teachers (with assistance from academics); using qualitative methods with a goal of making practical improvements to their own practice (Kemmis \& McTaggart, 2005). Emphasis is on the interpretations teachers and students make in their situations and environments (Kemmis \& McTaggart, 2005; Stringer, 2008).

A recent example of the use of practical action research is a study by Yoo and Kang (2018) in which the authors sought to determine how music instructors responded to their experiences of rehearsing within a Korean percussion ensemble piece. Specifically, the authors sought to assess the effectiveness of instructional approaches used when teaching a Korean percussion ensemble piece "Salmulnori" to both preservice music teachers and preservice classroom instructors (Yoo \& Kang, 2018). Data collection methods included reflective narratives produced by the instructor and participants, observation field notes, and participant interviews, with the research participants made up of 7 preservice music teachers and 9 preservice classroom teachers (Yoo \& Kang, 2018). An example of the types of questions participants where asked included: "What were your overall impressions about the lesson?" and "Please share your suggestions on how to make this experience better" (Yoo \& Kang, 2018, p. 74). This approach to action research differs from the previously mentioned technical action research as the research participants were encouraged to reflect upon their rehearsal experiences in an unstructured format and were also encouraged to freely comment on as many aspects of the rehearsal session as possible (Yoo \& Kang, 2018). Consistent with the practical action research and the interpretivist paradigm, participant debriefing aided in the interpretation of data and the coding process (Yoo \& Kang, 2018). 


\section{Emancipatory Action Research \& the Critical Theory Paradigm}

Epistemology \& Ontology. Critical theory originated in the 1920 s by a group of Marxistorientated German scholars working in what has become known as The Frankfurt School (Munhall, 2012; Polit \& Beck, 2012; Thomas, 2010), and basing their ideas on Marx, Kant, and Hegel (Thomas, 2010). A researcher working within a critical theory perspective is concerned with critiquing society and envisioning new possibilities (Polit \& Beck, 2012). Critical theory is action oriented, with a broad aim to integrate theory and practice so people become aware of contradictions and disparities in their social practices and beliefs in order to become inspired to change those situations (Polit \& Beck, 2012). Critical theorists hold an epistemology which states knowledge is acquired through a transaction between researcher and participants, therefore the perceptions and standpoints of both influence knowledge generation and creation (Cameron \& Singh, 2013). Researcher and participant perceptions are influenced by context so contextual awareness and its relationships to all research participants is one of the focuses of research under this paradigm (Cameron \& Singh, 2013).

The emancipatory form of action research employs praxis as being fundamental to gaining knowledge in an emancipatory context (McCutcheon \& Jung, 1990). Action informs reflection allowing people to see their social conditions and themselves more clearly (Maguire, 1987). Emancipatory action research has a goal of releasing human potential and examines ideology and power within organizations and society (Herr \& Anderson, 2015) in order to free participants from the directives of tradition, habit, precedent, coercion or selfdeception (Carr \& Kemmis, 1986; Herr and Anderson, 2015). These directives are believed to be subtle, yet deeply embedded in the belief structure of organizations and through a process of self-reflection, can be brought to the surface and examined; eventually leading to transformation (Herr \& Anderson, 2015). This form of action research has an epistemology which states knowledge is gained by understanding the constraints of equality within society and structures (Masters, 1995).

Critical theory has an ontology which states reality is often constructed by those with power, and reality is shaped by political, social, economic, and cultural forces (Cameron \& Singh, 2013). Likewise, the emancipatory form of action research is based on an ontology that assumes that social reality is historically created and is produced and reproduced by people (Myers, 2009). Emancipatory action research aims to not only improve outcomes and the understandings of practitioners, but also to help practitioners in critiquing their social or education work and work environments (Kemmis, 2001). This form examines the social, historical, and cultural processes of everyday life to reconstruct the practice (or work), the practitioner (or worker), and also the actual practice setting (or workplace) (Kemmis, 2001). This examination helps the practitioner in understanding that goals are often defined by particular individuals or by organizations and therefore, may be limited given the wider lens of the situation and environment in which we live or work (Kemmis, 2001).

Belief. The aim of emancipatory action research is to critique the status quo, focus on conflicts and constraints in society, and bring about social, cultural, and political change 
with a belief this will assist in eliminating causes of alienation and domination (Thomas, 2010). Emancipatory action researchers aim to help practitioners in developing a critical and self-critical understanding of their situation and environment (Kemmis, 2001). Emancipatory action researchers require their method of inquiry to incorporate a set of social values including: democracy (encouraging the participation of all those involved); equitability (acknowledging participants worth); liberation (is free from oppressive conditions); and enrichment (encourages the expression of participants' full human potential) (Stringer, 2007).

Claims to Truth. Critical theorist researchers attempt to discover truth and understanding within a social context (Reeves \& Hedberg, 2003). This paradigm posits that events are understood in relation to social and economic hindrances to true equality (Masters, 1995) and that no one or no one paradigm has a monopoly on truth (Maguire, 1987). Aligned with these theories, emancipatory action researchers believe truth is revealed when one acts upon the conditions one faces in order to change them (O'Brien, 1998). This form examines the ethical and political lives of participants and rejects the notion of researcher neutrality, believing that the active researcher often has the most at stake when resolving a problematic situation (O’Brien, 1998).

Example. One thread of emancipatory action research is the work of Patricia Maguire (1987) who applied a feminist approach to participatory research (Young, 2013). Maguire (1987) believed that women often are in the periphery in most participatory research literature. Participatory research starts with a premise that knowledge has become the single most important root of power and control, and that ordinary people are rarely considered knowledgeable (Maguire, 1987). A major thread of emancipatory action research is participatory action research (Kemmis \& McTaggart, 2005; Savin-Baden \& Wimpenny, 2007).

An example of a research study incorporating emancipatory action research is Oliveira, Soares, and Silva's (2016) work with thirteen students at a public school in São Paulo. The purpose of the study was to create a drug awareness media program. Using emancipatory action research within a critical theory paradigm allowed the young students to take hold of the discussion process as a right to critically reflect on the relationship between capitalism and drug use (Oliveira, Soares, \& Silva, 2016). The researchers were motivated by the fact that drug education is often lacking the participation of young people, makings these messages almost insignificant for this group in general (Oliveira, Soares, \& Silva, 2016). Consistent with emancipatory action research, the researchers invited participantssocial groups (students) that face the problems--to critically problematise the reality they face (Oliveira, Soares, \& Silva, 2016). Further, the students were encouraged to seek information and other tools to understand the problems and relate them to their social context (Oliveira, Soares, \& Silva, 2016). This allowed the students to uncover the social network of causality that involved said problem and "create proposals to mobilise and strengthen the groups involved and transform the causes of the detected adversities" (Oliveira, Soares, \& Silva, 2016, p. 1983). Further, throughout the research study, there was concern in reaching the goal of a collective construction of knowledge, while not losing 
sight of the importance of the effective participation of the students (Oliveira, Soares, \& Silva, 2016). Therefore, a group-created social network was used to exchange information (Oliveira, Soares, \& Silva, 2016). It was found that with the utilization of emancipatory action research, the students were able to claim the group space as their own, and articulate their right to the space, resulting in an investigated phenomenon which collated with their social reality, that is, with forms of their work, life, and sociability (Oliveira, Soares, \& Silva, 2016).

\section{PARTICIPATORY ACTION RESEARCH}

Participatory action research (PAR) emerged from efforts such as cooperative inquiry and is aimed at achieving a "clearer focus on the needs of participants involved in the research process than earlier approaches" (Savin-Baden \& Wimpenny, 2007, p. 332). PAR aspires to help people release themselves from the constraints of unjust, irrational, unproductive, and unsatisfying social structures (Kemmis \& McTaggart, 2005). PAR allows participants to describe how their practices are shaped and constrained by political, economic, and cultural structures and if they can intervene on their own behalf to escape these constraints, and if not, how they can work within these structures to minimize the irrationality, dissatisfaction, and inefficiencies within (Kemmis \& McTaggart, 2005).

Not all action research approaches are fully participative (such as technical action research) (Bergold \& Thomas, 2012), however, with PAR, participation is a fundamental part of the research practice. It can assist marginalized people in attaining a degree of emancipation within their situation or environment (Freire, 1982), while challenging social norms and assumptions that keep persons marginalized and oppressed (Chenail et al., 2012). Whereas in technical action research, those affected by the research may not actually participate in the research process, with PAR a degree of participation is typically achieved by every participant, although the level of participation may vary among participants -- and others will also likely be affected by the research. In PAR, people join together to tackle issues which affect them within their daily lives (Park, 2001). Therefore, the group process is important in a PAR project and so too is dialogue between researcher and co-researchers due to its existential significance for human life (Park, 2001).

Participatory action research follows an epistemology that knowledge is relative (Reason, 1994), and that knowledge generation is the result of participant participation in the entire research process (Brydon-Miller, Kral, Maguire, Noffke, \& Sabhlok, 2011; Young, 2013). Therefore, participatory action researchers' encourage and pay close attention to ordinary people's (participants) knowledge (Fals Borda, 2001). They do this based on the belief that combining popular thought and academic science creates a more complete and applicable knowledge (Fals Borda, 2001). This premise "democratizes research" (Young, 2013, p. 319), resulting in "transformative potential" (Young, 2013, p. 319), while addressing issues such as power and hierarchy which are present in traditional positivist research approaches, allowing those affected within the research to benefit from a more democratic research experience (Young, 2013). 
PAR is not simply a quest for knowledge, but also attempts to transform attitudes, values, personality, and culture (Fals Borda, 2001). PAR challenges traditional hierarchies between researcher and researched (Kindon, Pain, R., \& Kesby, 2007) and is a social process creating knowledge from all persons involved in the research (Brydon-Miller et al., 2011). PAR challenges larger rules and structures which keep issues and problems in place (Chenail et al., 2012).

Participatory action research (PAR) embraces an epistemology which accommodates the reflexive capacities of humans within the research process. PAR accommodates ontology that humans are dynamic agents capable of reflexivity and self-change (Kindon, Pain \& Kesby, 2007). Action research threads which originate from the technical and practical forms of action research do not subscribe to these principles as technical and practical forms of action research are primarily researcher-driven.

Participatory action research has been used within educational settings, largely due to the work of Paulo Freire (2005) who studied oppressive educational environments in Brazil and introduced key concepts of participatory action research: dehumanization; the difference between subjects versus objects in research; co-intentional education, and the 'banking' concept of education. Freire's thoughts on equality, partnerships, control, and student and instructor as teachers in educational environments influenced the use of PAR in education. Stakeholders reflect upon each other's thinking and become "jointly educated" (Freire, 2005, p. 109). Freire believed hierarchies can only be eliminated when one is prepared to engage in open, reciprocal dialogue with another.

Freire's concept of the 'banking' of education is one in which the teacher instructs and narrates and the student listens, memorizes and regurgitates the information for an upcoming test or examination (Freire, 2005). In this experience, education is "an act of depositing, in which the students are the depositories and the teacher is the depositor" (Freire, 2005, p. 72). Contrary to this oppressed dynamic between teacher and student, Freire (2005) introduced the concept of conscientization. Conscientization, rather than integrating students into the existing structure of oppression, seeks to transform the structure itself in order that students may become fully human and "beings for themselves" (Freire, 2005, p. 74). Rather than simply recipients of knowledge and information, students become more conscious beings which dehumanizes power between teacher and student and recognizes that education is focused on cognition as opposed to simply a transfer of information (Freire, 2005). Within this spirt of conscientization, both/all parties grow and "people teach each other" (Freire, 2005, p. 80), with teachers presenting material for students to consider, while re-considering their own considerations as students express their thoughts and beliefs (Freire, 2005). These concepts are central to participatory action research in which the researcher is not considered the expert but is also a participant and learner in the research process, just as teachers embodying conscientization become participants and learners in the educational process. 


\section{Tensions Associated with Participatory Action Research}

Power. A research project utilizing participatory action research is one in which the issue of power is examined with a goal of reducing and/or eliminating power between researcher and participants. However, this is not an easy task in any relationship. As Gaventa and Cornwall (2001) state, no human relationship is exempt from a power element(s). Power is present in traditional research environments.

Foucault (1977) stated power does not necessarily reside in individuals but in the positions they occupy, therefore the researcher may be assumed to have more power than the participants and/or co-researchers (Gaventa \& Cornwall, 2001). The research environment can be a place where power is assumed by various persons at various times during the research process. Power itself is not negative; it depends upon what one does with it (Hooks, 1994). Power can be used as an exercise of power with others rather than power over others (Gaventa \& Cornwall, 2001), and can also be seen as the power to be in solidarity with others and as the power to act on moral values (Park, 2001) and create positive change.

Role of the Researcher. Often the role of the researcher in the project and their role within the organization where the research is taking place add a layer of complexity within the research process. This duality of roles can create role ambiguity and conflict (Chenail et al., 2012). Research within organizational settings will be influenced not only by the theoretical foundations of PAR, but also by the larger institutional context in which the research takes place. Therefore, it is important for the researcher to be aware of the political conditions which exist in these institutions in order to be prepared to manage any political and ethical dynamics which may arise during the research process (Coghlan \& Casey, 2001; Williamson \& Prosser, 2002). The institution in which the researcher plans to conduct research may also be a place which also employs the researcher after the research ends (Herr \& Anderson, 2015). This is a dynamic the researcher needs to acknowledge, be cognisant of and address at the beginning and during the research process.

\section{CONCLUSION}

This paper stated three main purposes: to describe action research as a research methodology; to examine the worldviews in social science that have informed the evolution of the three main "umbrella" forms of action research; and to further describe a thread of action research which has grown in popularity recently: participatory action research.

Just as social science research has evolved, so too has action research. Threads of action research have expanded from a positivist empirical form to more emphasis on critical and emancipatory principles. This emancipatory paradigm forces researcher and participants to challenge existing hierarchies and power issues in order to make positive change. Participatory action research is not only a research methodology; it is a philosophy of life (Pine, 2009; Reason \& Bradbury, 2001). A PAR research methodology offers all research participants an opportunity to be co-researchers from the beginning to the end of the research process, encouraging critical thinking skills and offering the researcher and those researched the rare opportunity to work together in a new and different way. The goals, 
assumptions, and claims to truth associated with PAR are closely aligned with values of democracy, collaboration, participation, and non-hierarchical practices as a means to greater understanding and improved practice in various organizations and institutions.

\section{REFERENCES}

Adelman, C. (1993). Kurt Lewin and the origins of action research. Educational Action Research, 1(1), 7-24.

Bergold, J., \& Thomas, S. (2012). Participatory research methods: A methodological approach in motion. Forum: Qualitative Social Research, 13(4), 191-222.

Borg, W. R., Gall, J. P., \& Gall, M. D. (1993). Applying educational research: A practical guide (3rd ed.). New York: Longman.

Brydon-Miller, M., Kral, M., Maguire, P., Noffke, S., \& Sabhlok, A. (2011). Jazz and the banyan tree: Roots and riffs on participatory action research. In N. K. Denzin \& Y. S. Lincoln (Eds.), The Sage handbook of qualitative research (4th ed.) (pp. 27-42). Los Angeles: SAGE.

Cameron, C., \& Singh, M. D. (2013). Nursing research in Candida: Methods, critical appraisal, and utilization ( $3^{\text {rd }}$ Canadian ed.). Toronto: Elsevier.

Carr, W., \& Kemmis, S. (1986). Becoming critical: Education, knowledge and action research. London: Falmer Press.

Chenail, R. J., St. George, S., Wulff, D., \& Cooper, R. (2012). Action research: The methodologies. In P. L. Munhall (Ed.). Nursing research: A qualitative perspective (5 ${ }^{\text {th }}$ ed.) (pp. 455-470). Sudbury, MA: Jones \& Bartlett Learning.

Chichester, M., \& Dennie, M. (2010). Peer mentoring: When nurses share time and expertise, everyone wins. Nursing for Women's Health, 14(3), 235-237.

Cochran-Smith, M. \& Lytle, S. L. (1993). Inside/outside: Teacher research and knowledge. New York: Teachers College Press.

Coghlan, D., \& Casey, M. (2001). Action research from the inside: Issues and challenges of doing action research in your own hospital. Journal of Advanced Nursing, 35(3), 674682.

Cooper, M. D. (1990). Mentorship: The key to the future professionalism in nursing. Journal of Pre-natal and Neonatal Nursing, 4(3), 71-77.

Corey, S. (1953). Action research to improve school practices. New York: Teachers College Press. 
Crotty, M. (1998). The foundations of social research: Meaning and perspectives in the research process. Los Angeles: SAGE.

Dewey, J. (1938). Experience and education. New York, NY: Touchstone.

Elliott, J. (1993). Reconstructing teach education. London: Falmer Press.

Fals Borda, 0. (2001). Participatory (Action) Research and social theory: Origins and challenges. In P. Reason \& H. Bradbury (Eds.), Handbook of Action Research (pp. 2737). London: SAGE.

Freire, P. (1982). Creating alternative research methods. In B. Hall, A. Gillette, \& R. Tandon (Eds.), Creating knowledge: A monopoly? (pp. 29-37). New Delhi: Participatory Research in Asia.

Freire, P. (2005). Pedagogy of the oppressed. New York: The Continuum International Publishing Group Inc.

Foucault, M. (1977). Discipline and punishment. London: Allen Lane.

Gaventa, J., \& Cornwall, A. (2001). Power and Knowledge. In P. Reason \& H. Bradbury (Eds.), Handbook of action and research: Participative inquiry and practice (pp. 7080). London: SAGE.

Greenwood, D. J., \& Levin, M. (1998). Introduction to action research: Social research for social change. Thousand Oaks: SAGE.

Grundy, S. (1982). 'Three modes of action research'. Curriculum Perspectives, 2: 3, p. 23-34.

Grundy, S. (1988). Three modes of action research. In S. Kemmis \& R. McTaggart (Eds.), The action research planner ( $3^{\text {rd }}$ ed.) (pp. 353-364). Victoria: Deakin Press.

Gustavsen, B. (2001). Participatory (action) research in social theory: Origins and challenges. In P. Reason \& H. Bradbury (Eds.), Handbook of action and research: Participative inquiry and practice (pp. 17-26). London: SAGE.

Habermas, J. (1971). Knowledge and human interests. Boston: Beacon Press.

Habermas, J. (1972). Communication and the evolution of society. Boston: Beacon Press.

Henning, E., van Rensburg, W., \& Smit, B. (2004). Finding your way in Qualitative Research: A beginner's guide. Pretoria: van Schaik Publishers. 
Herr, K., \& Anderson, G. L. (2015). The action research dissertation: A guide for students and Faculty. Los Angeles: SAGE.

Holter, I. M., \& Schwartz-Barcott, D. (1993). Action Research: What is it? How has it been used and how can it be used in nursing? Journal of Advanced Nursing, 18(2), 298304.

hooks, b. (1994). Teaching to transgress: Education as the practice of freedom. New York: Routledge.

Hopper, T. F. (2006). Learning to respond: Supervising novice physical educators in an action research project. Sport, Education and Society, 2(2), 163-180.

Kemmis, S. (2001). Exploring the relevance of critical theory for action research: Emancipatory action research in the footsteps of Jurgen Habermas. In P. Reason \& H. Bradbury (Eds.), Handbook of action and research: Participative inquiry and practice (pp. 91-102). London: SAGE.

Kemmis, S., \& McTaggart, R. (2005). Participatory action research: Communicative action in the public sphere. In N. K. Denzin \& Y. S. Lincoln (Eds.). The Sage handbook of qualitative research ( $3^{\text {rd }}$ ed.) (pp. 559-603). Thousand Oaks, CA: SAGE.

Kindon, S., Pain, R., \& Kesby, M. (Eds.) (2007). Participatory action research approaches and Methods: Connecting people, participation and place. London: Routledge, Taylor \& Francis Group.

Koch, T., \& Kralik, D. (2006). Participatory action research in health care. Malden, MA: Blackwell Publishing.

Kuhn, T. S. (1962). The structure of scientific revolutions. Chicago, IL: University of Chicago Press.

Langford, R., \& Young, A. (2013). Making a difference with nursing research. Boston: Person.

Lucock, M., Barber, R., Jones, A., \& Lovell, J. (2007). Service users' views of self-help strategies and research. United Kingdom Journal of Mental Health 16(6), 795-805.

Ludema, J. D., Cooperrider, D. L., \& Barrett, F. J. (2001). Appreciative inquiry: The power of the unconditional positive question. In P. Reason \& H. Bradbury (Eds.), Handbook of action and research: Participative inquiry and practice (pp. 188-199). London: SAGE.

Maguire, P. (1987). Doing participatory research: A feminist approach. Amherst, MA: Center for International Education, University of Massachusetts. 
Masters, J. (1995). The history of action research. In I. Hughes (Ed.), Action research electronic reader. The University of Sydney. Retrieved 08.13.2016 from http://www.behs.cchs.usydedu.au/arow/Reader/masters.hum.

McCutcheon, G., \& Jung, B. (1990). Alternative perspectives on action research. Theory into Practice, 29(3), 144-151.

McTaggart, R. (1992). Action research: Issues in theory and practice. Keynote address to the Methodological Issues in Qualitative Health Research Conference, Friday November 27, 1992. Geelong: Deakin University.

Noffke, S. E. (1997). Professional, personal, and political dimensions of action research. Review of Research in Education, 22, 305-343.

Noffke, S., \& Somekh, B. (2011). Action research. In B. Somekh \& C. Lewin (Eds.), Theory and methods in social research (2nd ed.) (pp. 94-101). Los Angeles: SAGE.

O'Brien, R. (1998). An overview of the methodological approach of action research. In R. Richardson (Ed.), Theory and practice of action research. Retrieved 08.13.2016 from http://www.web.ca?-robrien/papers/arfinal.html.

Oliveira, E., Soares, C., \& Silva, J. (2016). Emancipatory action research with young schoolchildren: Experience report. SciELO Brasil, 37(3), 1983-1447.

Park, P. (2001). Knowledge and participatory research. In P. Reason \& H. Bradbury (Eds.), Handbook of action research: Participative inquiry and practice (pp. 81-90). London: SAGE.

Pine, G. J. (2009). Teacher action research: Building knowledge democracies. Thousand Oaks, California: SAGE.

Polit, D. F. \& Beck, C. T. (2012). Nursing research: Generating and assessing evidence for nursing practice (9th ed.). Philadelphia: Lippincott Williams \& Wilkins.

Reason, P. (Ed.). (1994). Participation in human inquiry. London: SAGE.

Reason, P. \& Bradbury, H. (2001). Introduction: Inquiry and participation in search of a world worthy of human aspiration. In P. Reason \& H. Bradbury (Eds.), Handbook of action research: Participative inquiry and practice (pp. 1-14). London: SAGE.

Reeves, T., \& Hedberg, J. G. (2003). Interactive learning systems evaluation. Englewood Cliffs, NJ: Educational Technology Publications.

Sagor, R. (1992). How to conduct collaborative action research. Alexandria, VA: Association for Supervision and Curriculum Development. 
Savin-Baden, M., \& Wimpenny, K. (2007). Exploring and implementing participatory action research. Journal of Geography in Higher Education, 31(2), 331-343.

Schaefer, R. I. (1967). The school as a center of inquiry. New York: Harper \& Row.

Somekh, B. (1995). The contribution of action research to development in social endeavours: A position paper on action research methodology. British Educational Research Journal, 21(3), 339-355.

Somekh, B., \& Lewin, C. (2005). Research methods in the social sciences. Thousand Oaks, California: SAGE.

Souleles, N. (2012). An action research project on the use of Facebook in an undergraduate visual communication study unit. Art, Design \& Communication in Higher Education, 11(2), 127-141.

Streubert, H. J., \& Carpenter, D. R. (2011). Qualitative research in nursing. Advancing the humanistic imperative (5th ed.). Philadelphia: Lippincott, Williams, \& Wilkins.

Stringer, E. T. (2007). Action research (3 ${ }^{\text {rd }}$ ed.). Los Angeles: SAGE.

Stringer, E. T. (2008). Action research in education (2nd ed.). Upper Saddle River, New Jersey: Pearson.

Thomas, P. Y. (2010). Towards Developing a Web-Based Blended Learning Environment at the University of Botswana. (Doctoral dissertation). Retrieved from WorldCat Dissertations. (Accession No: OCLC: 755713731).

Walsham, G. (1993). Interpretive case studies in IS research: Nature and method. European Journal of Information Systems, 4, 74-81.

Walsham, G. (1995). The Emergence of Interpretivism in IS Research. Information Systems Research, 6(4,), 376-394.

Williamson, G. R., \& Prosser, S. (2002). Action research: Politics, ethics and participation. Journal of Advanced Nursing, 40(5), 587-593.

Yoo, H., \& Kang, S. (2018). Instructional approaches to teaching a Korean Percussion Ensemble (Samulnori) to preservice music teachers and preservice classroom teachers: An action research study. Journal of Music Teacher Education, 28(1), 7082. 
Young, L. E. (2013). Participatory action research: A new science for nursing? In C. T. Beck (Ed.), Routledge international handbook of qualitative nursing research (pp. 319330). London: Routledge.

Zeichner, K. (2001). Educational action research. In P. Reason \& H. Bradbury (Eds.), Handbook of action research: Participative inquiry \& practice (pp. 273-283). Thousand Oaks, California, SAGE.

Zuber-Skerritt, 0. (1992). Action research in higher education: Examples and reflections. London: Kogan Page Limited.

BIOGRAPHICAL NOTE:

Dr. Steven Darryl Jacobs is a professor in the Practical Nursing Program at George Brown College. He began in the health care field as a Health Care Aide. It was because of this experience that Steven decided to enter the field of nursing. Steven obtained his BScN (Honours) in 1995 from York University. He completed his Masters of Nursing from Athabasca University in 2008 and then a second Masters of Education from Central Michigan University in 2010. He also has a Certificate in The Teacher of Adults (Honours) program from Centennial College. Steven's nursing career has focused on palliative care both in hospital and community environments. He has been in nursing education for over 14 years in a variety of roles such as faculty, coordinator and Chair of the Nursing department at Centennial College. Steven has published 7 peer-reviewed articles and 2 non-peer-reviewed articles, the majority of which deal with mentorship in health care, action research, and student educational issues. Over the next few years, Steven hopes to finish and publish a mentorship manual for health-care professionals. Steven is married to a wonderful woman and they have two children currently attending university-and a dog and a cat. He loves running, punk rock music, and Jasmine tea, not necessarily in that order. 